\title{
Implementasi Sistem E-voting Untuk Meningkatkan Kualitas Demokrasi di Indonesia
}

\section{${ }^{1}$ Junior Hendri Wijaya}

${ }^{2}$ Achmad Zulfikar;

${ }^{3}$ Iman Amanda

Permatasari

\section{1,3 Universitas}

Muhammadiyah

Yogyakarta, Jl. Brawijaya,

Tamantirto, Kasihan, Bantul,

DIY, Indonesia

${ }^{2}$ Universitas Hasanuddin, Jl. Perintis Kemerdekaan $\mathrm{Km}$. 10, Makassar, South

Sulawesi, Indonesia

${ }^{1}$ Junior.hendri.2012@fisipol.umy.a c.id

2apa@kabarfikar.com

\section{Artikel Info:}

Diterima : 01 November 2019

Disetujui : 10 November 2019

Disetujui : 30 Desember 2019

\begin{abstract}
ABSTRAK
Indonesia berada di posisi ke enam yang menggunakan internet terbanyak di dunia. Peringkat ke enam terbesar ini di antara sekitar 3,6 miliar jumlah pengakses internet di dunia.Angka ini menunjukan pengguna internet di Indonesia cukup tinggi. Populasi indonesia yang berjumlah 265,4 juta dengan memiliki 50\% pengguna internet. Tujuan dari penelitian ini adalah untuk menganalisa Implementation of electronic voting to enhance the quality of democracy in Indonesia. Metode yang digunakan dalam penelitian adalah studi pustaka. Berdasarkan hasil temuan peneliti, Indonesia memiliki peluang besar dalam mengimplementasikan elektronik voting, sehingga penerapan ini dapat meningkatkan kualitas demokrasi di Indonesia. Berdasarkan fakta-fakta analisis SWOT yang lebih banyak menghasilkan peluang dan kekuatan untuk Indonesia, meskipun masih terdapat kelemahan dan ancaman dalam penerapan sistem E-voting dalam pemilu.
\end{abstract}

Kata kunci: Implementasi, E-Voting, Demokrasi, Indonesia

\section{ABSTRACT}

Indonesia is in the sixth position which uses the most internet in the world. The sixth largest ranking among around 3.6 billion internet users in the world. This figure shows that internet users in Indonesia are quite high. Indonesia's population is 265.4 million with 50\% of internet users. The purpose of this study is to analyze the Implementation of electronic voting to enhance the quality of democracy in Indonesia. The method used in research is literature study. Based on the findings of researchers, Indonesia has a great opportunity in implementing electronic voting, so that this application can improve the quality of democracy in Indonesia. Based on the facts of the SWOT analysis, there are more opportunities and strengths for Indonesia, although there are still weaknesses and threats in implementing the E-voting system in elections.

Keywords: Implementation, Electronic Voting, Democracy, Indonesia 


\section{PENDAHULUAN}

Indonesia merupakan salah satu negara yang menganut paham demokrasi, dalam melakukan pemilihan presiden serta wakil presiden, legislatif, bahkan pemilihan kepala desa dilakukan secara voting. Voting ini dimaksud dengan suatu cara untuk menentukan pilihan dengan mencoblos atau pun mencontreng pilihannya. Kegiatan ini dilakukan pada waktu-waktu tertentu. Di Indonesia peilihan umum dilaksanakan sesuai dengan undang-undang no. 7 Tahun 2017 tentang pemilihan umum.

Undang-undang No. 7 tahun 2017 tentang pemilihan umum terdiri dari atas 573 Pasal, penjelasan, dan 4 lampiran. Secara tegas menerangkan bahwa Pemilu dilaksanakan berdasarkan asas Langsung, umum, bebas, rahasia, jujur, dan adil. Dan dalam menyelenggarakan pemilu, penyelenggara pemilu harus melaksanakan Pemilu berdasarkan pada -asas sebagaimana dimaksud, dan penyelenggaraannya harus memenuhi prinsip: a. mandiri; b. jujur; c. adil; d. berkepastian hukum; e. tertib; f. terbuka; g. proporsional; h. profesional; i. akuntabel; j. efektif; dan k. Efisien (UU, 2017). Sesuai dengan keterangan dari uu tersebut, maka Indonesia diperlukan inovasi baru untuk menciptakan sistem voting dalam pemilu yang lebih sederhana yaitu sistem electronic voting.

Electronic Voting merupakan singkatan dari Evoting. Evoting berkaitan erat dengan egovernment. E-goverment yang merupakan suatu sistem teknologi informasi yang dikembangkan oleh pemerintah dalam memberikan pilihan kepada masyarakat. Dalam waktu kapanpun dan dimanapun untuk mendapatkan kemudahan akases informasi dan layanan yang diberikan oleh pemerintah (Anistiawati, 2014). Mengenai hal ini tentu menjadi alternatif bagi pemerintah yang memanfaatkan sebagai alternatif saluran pilihan melalui teknologi informasi ini.

Sementara itu, angka pengguna internet pun di Indonesia cukup tinggi. berdasarkan data yang ditemukan yang di tulis oleh Kemp, menyatakan bahwa indonesia yang total populasinya 265,4 juta memiliki 50\% pengguna internet, dari setengah jumlah pengguna internet tersebut adalah para digital native (Simon Kemp, 2018). Dari hasil ini, menempatkan negara Indonesia berada di posisi ke enam yang menggunakan internet terbanyak di dunia. Peringkat ke enam terbesar di antara sekitar 3,6 miliar jumlah pengakses internet di dunia (kominfo.go.id, 2014). Sehingga Indonesia bisa memanfaatkan sistem E-voting ini sebagai kebutuhan untuk meningkatkan kualitas demokrasi di Indonesia. Dari hasil ini peneliti perlu dikaji tentang implementation of electronic voting to enhance the quality of democracy in Indonesia.

\section{METODE PENELITIAN}

Metode penelitian yang digunakan adalah metode penelitian kualitatif. Pengumpulan data menggunakan literature review dikarenakan memang belum ada pengimplementasian sistem $E$ voting di Indonesia. Studi Pustaka yang digunakan untuk mencari berbagai konsep, teori, asas, aturan, dokumen yang berkaitan dengan penelitian (Fuadi, 2015). Menurut Ikhsan A dalam buku Kamus Pelajar, studi kepustakaan adalah penyelidikan mengenai semua buku, karangan dan tulisan tentang bidang ilmu, topik, gejala atau kejadian. Kaidah-kaidah studi kepustakaan yang harus diperhatikan peneliti adalah proses yang terdiri dari: identifikasi teori yang sistematis, penemuan pustaka, dan analisis dokumen informasi yang berhubungan dengan topik penelitian (Anwar, 2014). Selain itu, pengumpulan data juga dilakukan dengan observasi lapangan. Sumber data yang digunakan adalah sumber data Jenis dan sumber data yang digunakan dalam penelitian ini adalah data sekunder. Data didapatkan dari berbagai sumber yang telah ada. Sumber-sumber 
tersebut seperti jurnal, buku, majalah, laporan. menganalisis data, peneliti menggunakan teknik analisis isi. Menurut Kripendoff, analisis isi digunakan untuk mendapatkan inferensi yang valid dan kemudian diteliti ulang berdasarkan konteksnya (Mirzaqon T, 2017).

\section{KERANGKA TEORI}

\section{Pengertian Implementasi}

Secara konseptual implementasi dalam makalah ini dimaknai sebagai implementasi dalam kebijakan publik. Pakar yang mengawali studi implementasi adalah Douglas R. Bunker pada tahun 1970 di forum the American Association for the Advancement of Science. Pada awal kemunculannya studi implementasi dipahami sebagai proses implementasi kebijakan publik sebagai suatu fenomena sosial politik atau yang lazim disebut political game. Dalam konteks Indonesia, implementasi kebijakan menempatkan tahap implementasi pada posisi yang berbedabeda, namun pada prinsipnya setiap kebijakan publik selalui dengan implementasi kebijakan (Akib, 2012).

Dalam perkembangannya, implementasi menjadi tahap yang sangat menentukan dalam proses kebijakan. Pandangan tersebut dikuatkan dengan pernyataan bahwa tanpa implementasi yang efektif keputusan pembuat kebijakan tidak akan berhasil dilaksanakan. Implementasi kebijakan merupakan aktivitas yang terlihat setelah dikeluarkan keputusan yang sah dari suatu kebijakan yang meliputi upaya mengelola masukan untuk menghasilkan luaran bagi masyarakat (Akib, 2012).

Dari definisi di atas, maka dapat dipahami bahwa implementasi terhadap electronic voting dapat diukur ketika suatu keputusan pelaksanaannya telah disahkan oleh pembuat kebijakan dalam hal ini pemerintah.

\section{E-voting}

E-voting merupakan akronim dari electronic voting. Sebagaimana telah diurai secara sederhana bahwa e-voting berkaitan erat dengan e-government yakni suatu sistem teknologi informasi yang dikembangkan oleh pemerintah untuk memudahkan akses informasi dan layanan (Anistiawati, 2014) selain itu, E-voting juga mengarah pada tujuan E-Government yang menunjukan tujuan dari implementasi undang-undang ITE sehingga sudah disesuaikan dengan tujuan Undang-Undang Dasar Tahun 1945 (Permatasari \& Wijaya, 2019).

Secara teknis, Kahani mendefinisikan e-voting sebagai penggunaan komputer atau peralatan pemungutan suara dalam pemilihan. Selanjutnya, Smith dan Clark mendefinisikan e-voting sebagai salah satu metode pemberian suara dengan menggunakan komputer di bilik pada tempat yang ditentukan. Kemudian, Hajjar et. al. mencakup penggunaan komputer dan bukan penggunaan suara secara tradisional dengan surat suara. Zafar dan Pilkjaer mendefinisikan e-voting menggabungkan teknologi dengan proses demokrasi agar pemungutan suara lebih efisien, nyaman bagi pemilih (Priyono \& Dihan, 2015).

Lebih lanjut, Badan Pengkajian dan Penerapan Teknologi (BPPT) sebagai pionir dalam pengembangan e-voting di Indonesia mendefinisikan electronic voting (e-voting) sebagai suatu metode pemungutan suara dan penghitungan suara dalam suatu pemilihan dengan menggunakan perangkat elektronik. Secara rinci dan operasional, BPPT mendefinisikan sistem e-voting sebagai sebuah sistem yang memanfaatkan perangkat elektronik dan mengolah informasi digital untuk 
membuat surat suara, memberikan suara, menghitung perolehan suara, mengirim hasil perolehan suara, menayangkan perolehan suara, memelihara dan menghasilkan jejak audit (Jayadi Nas, Zulfikar, \& IP, 2019).

Dari definisi di atas, maka dapat dipahami bahwa electronic voting atau e-voting dimaknai secara luas sebagai sarana pemberian suara dengan menggunakan perangkat elektronik atau komputer. Lebih spesifik, BPPT merinci sistem e-voting berdasarkan tahapan-tahapan.

\section{Demokrasi}

Demokrasi berasal dari kata demos yang berarti rakyat dan kratos yang berarti kekuasaan atau pemerintahan berdasarkan bahasa Yunani. Dalam bentuk konkrit, demokrasi ditandai dengan adanya pemilihan kepala pemerintahan oleh rakyat. Asal mula penerapan demokrasi dilaksanakan di negara kota (city-state) Yunani Kuno pada abad ke-6 sampai abad ke-3 SM yang dijalankan secara langsung, dimana seluruh warga negara terlibat. Dalam perkembangannya demokrasi yang dijalankan berdasarkan perwakilan.

Pemerintahan yang semua warga negaranya memiliki hak setara dalam pengambilan keputusan yang dapat mengubah hidup mereka disebut sebagai pemerintahan demokratis. Demokrasi memberikan keleluasaan bagi warga negara untuk berpartisipasi baik secara langsung atau melalui perwakilan dalam perumusan, pengembngan dan pembuatan suatu kebijakan. Demokrasi mencakup kondisi sosial, ekonomi dan budaya yang memungkinkan adanya praktik politik yang bebas dan setara (Sardini, 2015).

Dari definisi di atas, maka diketahui bahwa demokrasi berkaitan erat dengan hadirnya rakyat dalam suatu pemilihan. Suatu negara dikatakan demokratis, bilamana negara tersebut menjamin hak-hak kebebasan dan kesetaraan rakyatnya dalam pemilihan.

\section{PEMBAHASAN DAN TEMUAN}

\section{Tinjauan E-voting di beberapa negara}

Berdasarkan data dari AEC project dalam sampai dengan bulan janari 2010, banyak negara yang menggunakan sistem e-voting hingga mencapai sebanyak 47 negara (Habibi, 2018). Adapun dari jumlah negara itu dapat di bedakan dalam 4 kategori. 4 kategori tersebut dapat dilihat pada tabel 1.Dari 4 indikator tersebut dapat di Selain dapat dikategorikan dari praktik pelaksanaannya selama ini, dari jumlah 47 negara tersebut, secara keseluruhan negara-negara tersebut juga dapat dibagi menjadi dua katagori lain, yaitu negara yang sukses dan negara yang tidak sukses. Negara yang sukses indikatornya adalah di negara tersebut e-voting telah dan tetap terus dipraktikkan dan mendapatkan respons positif dari rakyatnya dan juga pemerintah di negaranya.Sedangkan, negara yang tidak sukses menerapkan e-voting adalah negara yang pada praktiknya setelah dievaluasi terdapat sejumlah kendala dan bahkan mendapat penolakan dari masyarakatnya dan lebih jauh lagi, sampai akhirnya dihentikan Impelmentasinya (Habibi, 2018). 
Tabel 1. Negara yang melaksanakan atau merencanakan E-voting

\begin{tabular}{|c|c|c|c|}
\hline No & Kategori & Nama Negara & $\begin{array}{l}\text { Jumlah } \\
\text { Negara }\end{array}$ \\
\hline 1 & $\begin{array}{l}\text { E-voting dengan mesin } \\
\text { pemeilihan (mengikat secara } \\
\text { hukum) }\end{array}$ & $\begin{array}{l}\text { Australia, Brasil, Kanada, Prancis, } \\
\text { India, Jepang, Kazakhstan, Peru, } \\
\text { Rusia, Amerika Serikat, Uni Emirat } \\
\text { Arab, Venezuela }\end{array}$ & 12 \\
\hline 2 & $\begin{array}{l}\text { E-voting dengan internet } \\
\text { voting (mengikat secara } \\
\text { hukum) }\end{array}$ & $\begin{array}{l}\text { Australia, Austria, Kanada, Estonia, } \\
\text { Prancis, Jepang, Swiss }\end{array}$ & 7 \\
\hline 3 & $\begin{array}{l}\text { Perencanaan dan percobaan } \\
\text { e-voting (Tidak mengikat } \\
\text { secara hukum) }\end{array}$ & $\begin{array}{l}\text { Argentina, Azerbaijan, Belarus } \\
\text { Bulgaria, Chili, Republik Ceko, } \\
\text { Finlandia, Yunani, Italia, Latvia, } \\
\text { Lituania, Meksiko, Nepal, Nigeria, } \\
\text { Norwegia, Polandia, Portugal, } \\
\text { Rumania, Slovakia, Slovenia, } \\
\text { Afrtika Selatan, Spanyol, Korea } \\
\text { Selatan, Swedia }\end{array}$ & 24 \\
\hline 4 & $\begin{array}{l}\text { Pelaksanaan e-voting di } \\
\text { hentikan }\end{array}$ & Jerman, Irlandia, Belanda, Inggris & 4 \\
\hline
\end{tabular}

Fakta-fakta yang terdapat dalam artikel yang ditulis Worlchok yang menerangkan sejak pada tahun 1989-1990 India mulai menggunakan sistem E-voting secara ekspeimental pada pemilihan umum lokal di beberapa negara bagian. Pada tahun tersebut, merupakan percobaan awal sebanyak 16 Pemilihan Lokal di negara bagian dengan perincian lima Pemilihan Lokal di Madhya Pradesh, lima di Rajasthan, dan enam di Daerah Khusus Ibukota Delhi (NCT Delhi). Versi lain menyebutkan e-voting pertama kali diperkenalkan di India pada tahun 1982 dalam jumlah yang terbatas (Wustrow, Wolchok, \& Alex Halderman, 2010).

Di India, metode e-voting diimplementasikan dengan menggunakan mesin yang bernama Electonic Voting Machine (disingkat EVM) (lihat Gambar 1) (reuters, 2014). EVM itu sendiri adalah sebuah mesin yang kecil, unit komputer yang sederhana, yang merekam pilihan pemilih tanpa menggunakan kertas. EVM ditempatkan di setiap TPS di mana pemilu diselenggarakan.Mengikuti ketentuan hukum yang disetujui di tahun 1989 sebagai syarat untuk mengizinkan penggunaan EVM, EVM telah banyak digunakan di banyak pemilihan negara bagian tetapi awalnya tidak pernah digunakan di pemilu India secara keseluruhan. EVM disediakan oleh Electronic Corporation of India dan Bharat Electronics, di mana digunakan di 45 konstituensi (daerah pemilihan).Perusahaan perusahaan yang disebutkan di atas dimiliki oleh Pemerintah India. Di tahun 2009 Komisi Pemilihan Umum India menggunakan sekitar 1,4juta EVM untuk menyelenggarakan pemilu nasional (Reddy, 2011). 


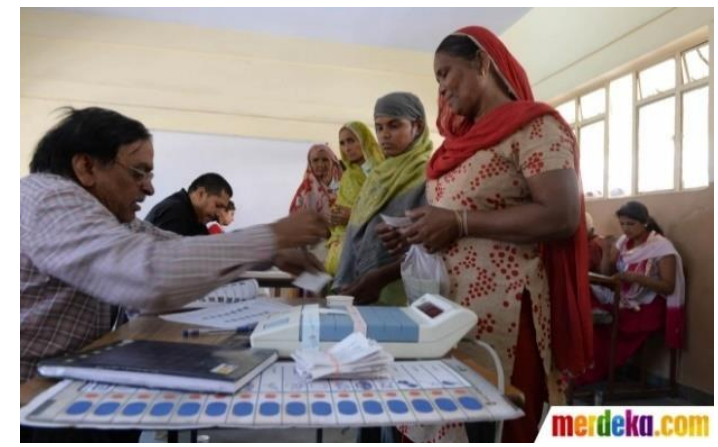

Gambar. 1 Mesin Electonic Voting Machine di India ((reuters, 2014)

Dengan adanya fakta tersebut, maka tidak heran apabila Indonesia menjadikan India sebagai contoh penerapan e-voting. Selain karena India telah berhasil melaksanakan sistem tersebut, negara ini pun memiliki kesamaan dalam beberapa hal dengan Indonesia, seperti jumlah masyarakat yang padat, sistem kenegaraan, dan tantangan dalam hal sarana prasarana.

\section{Gambaran Pelaksanaan E-voting di Indonesia}

Kualitas pemilihan umum di Indonesia sebenarnya saat ini sudah mengalami peningkatan signifikan dibanding tahun-tahun sebelumnya. Contohnya pada 2014, pemerintah mulai menerapkan teknologi pada sistem pendaftaran pemilihan umum untuk mempermudah dan mempersingkat proses. Daftar pemilih Indonesia pun berubah dari daftar yang dikumpulkan secara manual, menjadi daftar berbasis data yang terkomputerisasi, terpusat, dan mudah diakses oleh berbagai pihak. Hal ini tidak menutup kemungkinan bahwa ke depannya proses pemilihan umum secara elektronik (e-voting) akan menjadi pertimbanganbagi Indonesia untuk dapat mengatasi pelanggaran yang terjadi pada pemilihan umum (Seno Hartono, 2017).

Berdasarkan fakta jumlah pengguna dan kegunaan media baru mengalami peningkatan. Hampir seluruh kegiatan dapat terselesaikan melalui berbagai macam akses internetyang mudah didapat, seperti e-commerce,transportasi daring, e-toll, e-learning, dan beragam sumbangsih perkembangankecanggihan internet yang dipergunakandalam keseharian manusia. Melihat dari data yang menunjukan bahwa Indonesia termasuk peringkat ke enam sebagai pengguna internet terbanyak di dunia (Supratman \& Supratman, 2018).

Melihat dari gambaran pelaksanaan pemilu indonesia dan dikaitkan dengan jumlah pengguna internet di Indonesia, serta berkaca pada beberapa negara seperti India, Brazil, yang telah berhasil mengimplementasikan sistem e-voting, secara negara Indonesia ataupun India merupakan negara demokrasi yang memiliki lanskap populasi menantang, beragam, ditambah lagi dengan adanya tantangan logistic (rumahpemilu.org, 2016). Melihat kelebihan dan kelemahan dari e-voting, dapat dikatakan layak dan mungkin untuk diimplementasikan di Indonesia. Akantetapi, masih banyak daerah yang memerlukan perhatian khusus dari pemerintah dalam hal sarana dan prasarana untuk menunjangsistem e-voting ini misalnya dalam hal listrik, jaringan internet,tenaga ahli untuk sistem e-voting, masyarakat yang belum melekkomputer (Hardjaloka \& Simarmata, 2016). Walau demikian dengan segala keterbatasan, e-voting melalui inisiasi BPPT telah berupaya untuk berkontribusi secara konkrit dan signifikan dalam pengembangan sistem evoting. Hal ini berdasarkan data BPPT RI sejak 2013 hingga 2017, e-voting telah diterapkan pada 683 pemilihan kepala desa di 12 kabupaten (Jayadi Nas et al., 2019)

\section{Gambaran SWOT}

Kesiapan Indonesia dalam mengimplementasikan sistem e-voting dapat di analisa dengan melalui SWOT. Analisa ini dapat di telaah dalam tabel x. 


\begin{tabular}{|c|c|}
\hline S(Kekuatan) & W(Kelemahan) \\
\hline $\begin{array}{l}\text { 1. Indonesia negara hukum } \\
\text { 2. Penetapan undang-undang tentang sistem } \\
\text { E-voting di Indonesia }\end{array}$ & $\begin{array}{l}\text { 1. Jaringan internet yang belum } \\
\text { optimal. }\end{array}$ \\
\hline $\mathrm{O}$ (Peluang) & $\mathrm{T}$ (Ancaman) \\
\hline $\begin{array}{l}\text { 1. Pengguna Internet yang tinggi } \\
\text { 2. Mengatasi Money Politic }\end{array}$ & 1. Keamanan sistem E-voting \\
\hline
\end{tabular}

Sumber: Data, Peneliti

Kekuatan dari sistem E-voting di Indonesia, terdapat beberapa kekuatan yang dimiliki oleh Indonesia didalam mengimplementasikan sistem E-voting, yaitu:

1. Indonesia adalah negara hukum, tentu ini sangat menjadi kekuatan Indonesia didalam menetapkan undang-undang tentang sistem pemilu menggunakan sistem E-voting. Sehingga untuk mengimplementasikan sistem E-voting perlu ditegaskan.

2. Penetapan undang-undang, Indonesia sudah memiliki uu tentang pemilu, sehingga UU ini dapat di tindaklanjuti dengan memfokuskan ketetapan secara detail dalam mengimplementasikan sistem E-voting, sehingga ini akan menjadi dasar kekuatan dalam pelaksanaan sistem E-voting.

\section{(W) Kelemahan}

Kelemahan dalam penerapan sistem E-voting di Indonesia.adapun yang menjadi kelemahan di Indonesia dalam menggunakan internet adalah jaringan yang masih belum optimal. Faktanya adalah indonesia termasuk dalam 10 Negara dengan koneksi internet paling lemot di dunialaporan 10 negara dengan koneksi internet paling lambat di dunia. Dari kesepuluh daftar ini, Indonesia termasuk salah satunya. Dari hasil studi ini mengambil sampel lebih dari 1 juta pengguna OpenSignal untuk menggambarkan sekitar 19 miliar pengguna internet. Sampel tersebar di 87 negara dengan waktu pelaksanaan dari November 2016 hingga Januari 2017 (Jeko I. R., 2017).

\section{(O) Peluang}

Banyak peluang yang di dapat di Indonesia ketika dapat menerapkan sistem E-voting dalam pemilu, sebagai berikut:

1. Pengguna internet yang banyak, menjadi suatu peluang di indonesia dikarenakan melek internet akan memudahkan untuk mengimplementasikan sistem e-voting.

2. Mengatasi Money Politic.

Di era reformasi ternyata fakta temuan kasus money politic.Sehingga sistem e-voting juga bisa efektif untuk mengatasi money politics. Misalnya, Parpol A menjanjikan akan memberikan uang sekian rupiah asalkan si pemilih bisa menunjukkan foto tokoh $\mathrm{A}$ yang "dicoblos" dan ini dibuktikan dari foto di smartphone miliknya. e-voting bisa dibuat supaya di bagian akhir tampil pilihan gambar apa yang ingin difoto untuk bukti si pemilih. Jadi, sangat mungkin bahwa si pemilih sebenarnya mencoblos calon "B", 
tetapi meminta sistem e-voting menampilkan calon "A", sehingga ketika difoto, yang tampil adalah "A".

\section{(T) Ancaman}

Pengimplementasian sistem e-voting tentu akan menghadapi ancaman-ancaman baik itu ancaman dari internal maupun dari eksternal. Tentu kelemahan sistem e-voting berasal dari teknologi yang mendasarinya, internet.Sebuah sistem yang sangat rentan terhadap serangan keamanan (Hapsara, 2011). Tentu ancaman-ancaman ini digambarkan seperti hacker, sehingga dalam pelaksanaan sistem e-voting di Indonesia diperlukan keamanan yang ketat hingga di buat kebijakan sanksi-sanksi bagi pelaku hacker sistem ini.

\section{KESIMPULAN}

Berdasarkan hasil temuan peneliti, Indonesia memiliki peluang besar dalam mengimplementasikan elektronik voting, sehingga penerapan ini dapat meningkatkan kualitas demokrasi di Indonesia dilihat dari fakta-fakta gambaran analisis SWOT yang lebih banyak menghasilkan peluang dan kekuatan untuk Indonesia, meskipun masih terdapat kelemahan dan ancaman dalam penerapan sistem E-voting dalam pemilu. BPPT sebagai lembaga pemerintah yang menginisiasi implementasi e-voting tentu terus berupaya menyempurnakan sistem agar dapat digunakan secara nasional.

\section{DAFTAR PUSTAKA}

Akib, H. (2012). Implementasi Kebijakan: Apa, Mengapa dan Bagaimana. Jurnal Ilmiah Ilmu Administrasi Publik, 1(1), 1-11. https://doi.org/10.26858/jiap.v1i1.289

Anistiawati, M. L. (2014). Implementasi Kebijakan Penerapan Elektronik Voting (E-Voting) Dalam Pemilihan Kepala Desa (Studi Kasus: Pemilihan Kepala Desa di Desa Mendoyo Dangin Tukad, Kecamatan Mendoyo Kabupaten Jembrana) | CITIZEN CHARTER. 1(2), 1-12.

Anwar, R. (2014). Hal-Hal yang Mendasari Penerapan Kurikulum 2013. Humaniora, 5(1), 97-106. https://doi.org/10.21512/humaniora.v5i1.2987

Fuadi, A. B. (2015). Diajukan Kepada Fakultas Syari'ah Dan Hukum Universitas Islam Negeri Sunan Kalijaga Yogyakarta Untuk Memenuhi Sebagian Syarat-Syarat Memperoleh Gelar Strata Satu Dalam Ilmu Hukum. 69.

Habibi, M. (2018). Dinamika Implementasi E-voting di Berbagai Negara. https://doi.org/10.31227/osf.io/bu2ax

Hapsara, M. (2011). Skenario Hacking Sistem E-voting: Denial-of-Service Attack - part 01Kompasiana.com. Retrieved December 27, 2019, from https://www.kompasiana.com/evotingindonesia/5500d684a333114f75511db7/skenariohacking-sistem-e-voting-denial-of-service-attack-part-01

Hardjaloka, L., \& Simarmata, V. M. (2016). E-voting: Kebutuhan vs. Kesiapan (Menyongsong) EDemokrasi. Jurnal Konstitusi, 8(4), 579-604. https://doi.org/10.31078/jk\%x

Jayadi Nas, M. S., Zulfikar, A., \& IP, S. (2019). E-Voting Di Bantaeng: Mengubah Mindset Masyarakat. De La Macca (Anggota IKAPI).

Jeko I. R., J. (2017). 10 Negara dengan Koneksi Internet Paling Lemot di Dunia-Tekno Liputan6.com. Retrieved December 27, 2019, from https://www.liputan6.com/tekno/read/2892154/10-negara-dengan-koneksi-internetpaling-lemot-di-dunia 
Kemp, Simon. (2018). Digital in 2018: World's internet users pass the 4 billion mark. Retrieved from https:// wearesocial.com/blog/2018/01/global-digitalreport-2018

kominfo.go.id, kominfo. go. id. (2014). Kementerian Komunikasi dan Informatika. Retrieved December 27, 2019, from https://kominfo.go.id/content/detail/4286/pengguna-internetindonesia-nomor-enam-dunia/0/sorotan_media

Mirzaqon T, A. (2017). Studi Kepustakaan Mengenai Landasan Teori Dan Praktik Konseling Expressive Writing. Jurnal BK UNESA, 8(1). Retrieved from https://jurnalmahasiswa.unesa.ac.id/index.php/jurnal-bk-unesa/article/view/22037

Permatasari, I. A., \& Wijaya, J. H. (2019). Implementasi Undang-Undang Informasi dan Transaksi Elektronik Dalam Penyelesaian Masalah Ujaran Kebencian Pada Media Sosial. Jurnal Penelitian Pers Dan Komunikasi Pembangunan, 23(1), 27-41.

Priyono, E., \& Dihan, F. N. (2015). E-Voting: Urgensi Transparansi Dan Akuntabilitas. Seminar Nasional Informatika (SEMNASIF), 1(5). $\quad$ Retrieved from http://jurnal.upnyk.ac.id/index.php/semnasif/article/view/1198

Reddy, A. A. (2011). Case study on Indian EVMS using biometrics. International Journal of Engineering Science $\mathcal{E}$ Advanced Technology, 1(1), 40-42.

reuters, reuters. (2014). Foto: Menengok kecanggihan pemilu di India menggunakan e-voting| merdeka.com. Retrieved December 27, 2019, from https://www.merdeka.com/foto/dunia/349628/20140411002719-menengok-

kecanggihan-pemilu-di-india-menggunakan-e-voting-001-isn.html

rumahpemilu.org/, rumahpemilu. org. (2016, September 5). Apakah Mesin E-voting India Memiliki Tempat di Pemilu Indonesia? Retrieved December 27, 2019, from Rumah pemilu website: https://rumahpemilu.org/apakah-mesin-e-voting-india-memiliki-tempat-dipemilu-indonesia/

Sardini, N. H. (2015). Penyelenggara Pemilu di Dunia: Sejarah Kelembagaan dan Praktik Pemilu di Negara Penganut Sistem Pemerintahan Presidensial, Semipresidensial dan Parlementer. Jakarta.

Seno Hartono, T. (2017). Tantangan dan Peluang e-voting di Indonesia-Tekno Liputan6.com. Retrieved December 27, 2019, from https://www.liputan6.com/tekno/read/2855014/tantangan-dan-peluang-e-voting-diindonesia

Supratman, L. P., \& Supratman, L. P. (2018). Penggunaan Media Sosial oleh Digital Native. Jurnal Ilmu Komunikasi, 15(1), 47-60. https://doi.org/10.24002/jik.v15i1.1243

UU, R. (2017). Undang-undang No. 7 tahun 2017 tentang pemilihan umum.

Wustrow, E., Wolchok, S., \& Alex Halderman, J. (2010). (4) Security Analysis of India's Electronic Voting Machines. Retrieved December 27, 2019, from ResearchGate website: https://www.researchgate.net/publication/221609811_Security_Analysis_of_India's_Elect ronic_Voting_Machines 